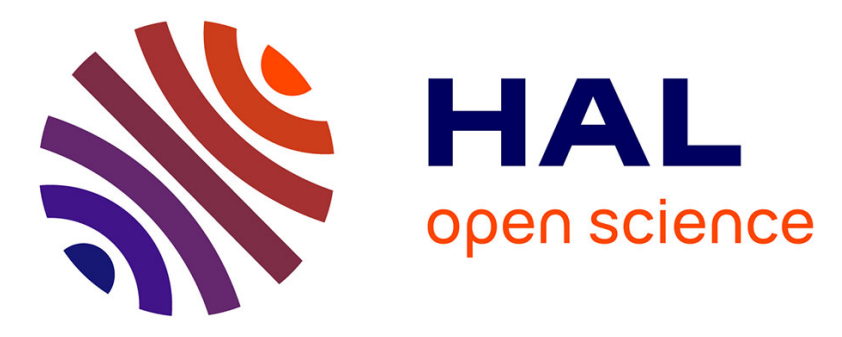

\title{
Synthesis and structural study of $\mathrm{N}$-isopropenylbenzimidazolone
}

Denise Mondieig, Philippe Negrier, Jean-Michel Léger," Loubna Lakhrissi, Abdeslam El Assyry, Brahim Lakhrissi, El Mokhtar Essassi, Bouziane Benali, Abdelkhalek Boucetta

\section{To cite this version:}

Denise Mondieig, Philippe Negrier, Jean-Michel Léger,, Loubna Lakhrissi, Abdeslam El Assyry, et al.. Synthesis and structural study of N-isopropenylbenzimidazolone. Russian Journal of Physical Chemistry A, Focus on Chemistry / Zhurnal fizicheskoi khimii, 2015, 89 (5), pp.807-811. 10.1134/S0036024415050271. hal-01155643

\section{HAL Id: hal-01155643 https://hal.science/hal-01155643}

Submitted on 27 May 2015

HAL is a multi-disciplinary open access archive for the deposit and dissemination of scientific research documents, whether they are published or not. The documents may come from teaching and research institutions in France or abroad, or from public or private research centers.
L'archive ouverte pluridisciplinaire HAL, est destinée au dépôt et à la diffusion de documents scientifiques de niveau recherche, publiés ou non, émanant des établissements d'enseignement et de recherche français ou étrangers, des laboratoires publics ou privés. 


\title{
Synthesis and Structural Study of $N$-Isopropenylbenzimidazolone ${ }^{1}$
}

\author{
D. Mondieig ${ }^{a}$, Ph. Negrier ${ }^{a}$, J. M. Leger ${ }^{b}$, L. Lakhrissi ${ }^{c, d}$, A. El Assyry ${ }^{*, e}$, \\ B. Lakhrissic ${ }^{c}$, E. M. Essassi ${ }^{d}$, B. Benali ${ }^{e}$, and A. Boucetta ${ }^{e}$ \\ ${ }^{a}$ Centre de Physique Moléculaire Optique et Hertzienne, Université Bordeaux1, 351 cours de la Libération Talence, France \\ ${ }^{b}$ Laboratoire de Pharmacochimie, EA4138 Université Victor Segalen Bordeaux2, 146 rue Léo Saignat, Bordeaux, France \\ ${ }^{c}$ Laboratoire d'Agroressources et Génie des procédés, Université Ibn Tofail, Département de Chimie, B.P. 133, Kénitra, Maroc \\ ${ }^{d}$ Laboratoire de Chimie Organique Hétérocyclique, Faculté des Sciences, Rabat, Maroc \\ ${ }^{e}$ Laboratoire d'Opto-électronique et de Physico-Chimie des Matériaux, (Unité associée au CNRST), Université Ibn Tofail, \\ Département de Physique, B.P. 133, Kénitra, Maroc \\ *e-mail: abdeslam_elassyry@yahoo.fr
}

\begin{abstract}
The synthesis and the crystal structure of the $N$-isopropenylbenzimidazolone $\left(\mathrm{C}_{10} \mathrm{H}_{10} \mathrm{~N}_{2} \mathrm{O}\right)$ are presented. The synthesis was performed by Meth-Cohen method by reaction of $o$-phenylenediamine with ethyl acetoacetate in refluxed xylene. The single crystal structure was determined at room temperature by means of X-rays diffraction. The crystal system is monoclinic, with space group $\mathrm{C} 2 / \mathrm{c}$ and eight molecules per unit cell. The unit cell dimensions are: $a=15.978(1) \AA, b=6.100(2) \AA, c=18.222(2) \AA, \beta=90.16(1)^{\circ}$ and $V=1776.0(6) \AA^{3}$.
\end{abstract}

Keywords: $N$-isopropenybenzimidazolone, synthesis, single crystal structure.

\section{INTRODUCTION}

Benzimidazolone is an interesting heterocycle. It is present in various natural compounds [1]. Its derivatives are known to have various pharmaceutical applications as novel NOP receptor agonists [2], progesterone receptor antagonists [3], they are also potential therapeutics for cystic fibrosis, chronic obstructive pulmonary disease, and have gastroprokinetic properties [4]. They can also be used as pigments [5]. Elsewhere, the benzimidazolone derivatives have biological activity [6-10] as well as complexant and surfactant properties [11-16].

It is known that the condensation of $o$-phenylenediamine 1 with ethyl acetoacetate 2 , in refluxed xylene during $1 \mathrm{~h}$, gives 4-methyl-1,5-benzodiazepin-1-one but by prolonging the reaction time for $6 \mathrm{~h}$, the authors have obtained $N$-isopropenylbenzimidazol-2-one-3 resulting from a sigmatropic rearrangement $[1,3]$ of the diazepinic ring [17].

Studies on thermal, structural, spectral and conformational properties of the benzimidazolone molecule were recently reported by our group [18-21]. In this paper, we describe the synthesis of $N$-isopropenylbenzimidazolone by the Meth-Cohen method [9], by the reaction of $o$-phenylenediamine with ethyl acetoacetate in refluxing xylene (Scheme 1). Then we present the $\mathrm{X}$-rays crystal structure analysis of this compound.
Table 1. Crystal data and structure refinement for $\mathrm{N}$-isopropenylbenzimidazolone

\begin{tabular}{l} 
Empirical formula: $\mathrm{C}_{10} \mathrm{H}_{10} \mathrm{~N}_{2} \mathrm{O}$ \\
\hline Formula weight $=174.2$ \\
Crystal system: Monoclinic \\
Space group: $C 2 / c, Z=8$ \\
Cell dimensions: $a=15.978(1) \AA, b=6.100(2) \AA$, \\
$c=18.222(2) \AA, \beta=90.16(1)^{\circ}$ \\
$V=1776.0(6) \AA^{3}$ \\
$T=296(2) \mathrm{K}$ \\
$D_{\text {cal }}=1.303 \mathrm{~g} / \mathrm{cm}^{3}$ \\
No. reflections used $=1514$ \\
$\mu\left(\right.$ Cu $\left.K_{\alpha}\right)=0.886 \mathrm{~mm}{ }^{-1}, \lambda=1.5418 \AA$ \\
$2 \theta_{\text {max }}=64.95^{\circ}$ \\
Crystal size $=0.25 \times 0.10 \times 0.10 \mathrm{~mm}$ \\
$F(000)=736$ \\
$R\left[I>2 \sigma\left(F^{2}\right)\right]=0.0344$ and $w R\left(F^{2}\right)=0.0851$ \\
Max. and min. transmission 0.9332 and 0.8443 \\
No. of parameters $=159$ \\
Goodness-of-fit on $F^{2}=1.067$ \\
Extinction coefficient $=0.0064(4)$ \\
Measurement Enraf-Nonius CAD4 \\
Program system: Enraf-Nonius SDP \\
Structure determination: SHELXL-97 \\
Refinement: full-matrix least-squares \\
\hline
\end{tabular}




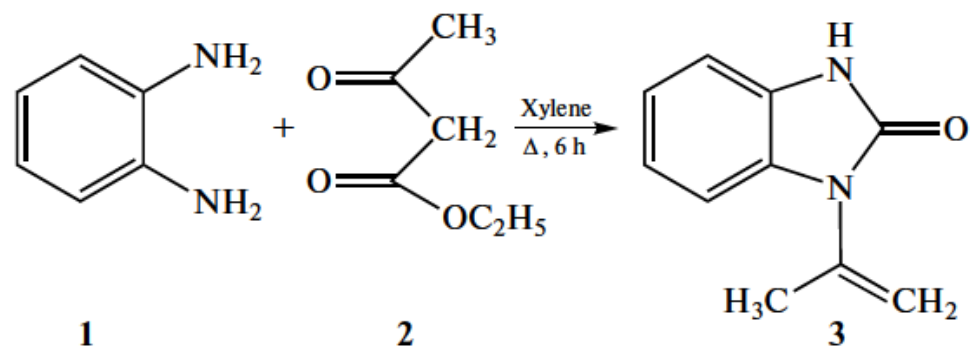

Scheme 1. $N$-Isopropenylbenzimidazolone synthesis.

\section{EXPERIMENTAL SECTION}

\subsection{Synthesis Control Methods}

Melting point was determined with an electrothermal IA 9200 digital melting point apparatus in capillary tubes and are uncorrected.

NMR spectra were recorded on a BRUKER AM 300 spectrometer operating at $300 \mathrm{MHz}$ for ${ }^{1} \mathrm{H}$ and $75 \mathrm{MHz}$ for ${ }^{13} \mathrm{C}$ in $\mathrm{CDCl}_{3}$. Chemical shifts are reported in $\delta$ units $(\mathrm{ppm})$ relative to internal $\mathrm{SiMe}_{4}$ standard.

\subsection{X-rays Diffraction}

A colorless single crystal $(0.25 \times 0.10 \times 0.10 \mathrm{~mm})$ was selected and mounted on an ENRAF-NONIUS CAD4 diffractometer equipped with a charge coupled device (CCD) detector using the $\mathrm{Cu} K_{\alpha}$ radiation $(\lambda=$ $1.5418 \AA$ ). 1514 reflexions were collected in the 4.85 to $64.95^{\circ} \theta$ range. The details of data collection are given in Table 1. The structure was solved by direct methods. The non-hydrogen atoms were located from the difference Fourier maps and further refined anisotropically by full-matrix least-squares to final reliability values of 0.0344 . All hydrogen atoms were refined isotropically. Refinements were carried out using SHELXL-97 [22]. Molecular structures were drawn using ORTEP and Material studio software [23].

\section{RESULTS AND DISCUSSION \\ 3.1. Synthesis}

To a mixture of $o$-phenylenediamine 1 (51.0 g, $0.47 \mathrm{~mol})$ with xylene $(200 \mathrm{~mL})$, an ethyl acetoacetate $(69.0 \mathrm{~g}, 0.53 \mathrm{~mol})$ solution in xylene $(30 \mathrm{~mL})$ was added dropwise within $10 \mathrm{~min}$. The reaction mixture was refluxed for $6 \mathrm{~h}$. The water and ethanol formed were removed progressively by an azeotropic distillation. The mixture was then cooled and the precipitated white solid was collected by filtration, washed two times with ether, dried in the oven to give the first portion of $N$-isopropenylbenzimidazolone $(55.0 \mathrm{~g})$. The filtrate was then treated with $20 \% \mathrm{NaOH}(400 \mathrm{~mL})$, the $N$-isopropenylbenzimidazolone salt was filtered, treated with acetic acid $(25 \mathrm{~mL})$ to give the second portion of $N$-isopropenylbenzimidazolone $(5 \mathrm{~g})$. The precipitate was then filtered, washed several times with water and diethyl ether and dried in the oven. (Total yield $\sim 70 \%$ ). The compound structure was confirmed by ${ }^{1} \mathrm{H}$ and ${ }^{13} \mathrm{C}$ NMR spectroscopy, m.p. $120-122^{\circ} \mathrm{C}$, ${ }^{1} \mathrm{H}$ NMR $\left(\mathrm{CDCl}_{3}\right): \delta 2.10\left(3 \mathrm{H}, \mathrm{s}, \mathrm{CH}_{3}\right), \delta 5.10(1 \mathrm{H}, \mathrm{s}$, $\left.\mathrm{H}^{2 \mathrm{a}}\right), \delta 5.30\left(1 \mathrm{H}, \mathrm{s}, \mathrm{H}^{2 \mathrm{~b}}\right), \delta 6.95-7.05\left(4 \mathrm{H}, \mathrm{m}, \mathrm{H}_{\text {arom }}\right)$, $\delta 10.70(1 \mathrm{H}, \mathrm{s}, \mathrm{NH}) ;{ }^{13} \mathrm{C}$ NMR $\left(\mathrm{CDCl}_{3}\right): \delta 19.6 ; 19.7$ $\left(\mathrm{CH}_{3}\right), \delta 112.0\left(=\mathrm{CH}_{2}\right), \delta 137.6(\mathrm{NC}), \delta 108.5(\mathrm{C}-4)$, $\delta 108.9(\mathrm{C}-7), \delta 120.6(\mathrm{C}-5), \delta 121.2$ (C-6), $\delta 128.5$ (C-8), $\delta 129.4(\mathrm{C}-9), \delta 152.7(\underline{\mathrm{C}}=\mathrm{O})$.

\subsection{Crystal Data}

$\mathrm{N}$-isopropenylbenzimidazolone structure was determined at room temperature. The details of structure analysis are given in Table 1 and an ORTEP plot of the molecule is shown in Fig. 1. The compound crystallizes in monoclinic $C 2 / c$ group and contains $8 \mathrm{~mol}-$ ecules per unit cell. The atomic coordinates and equivalent isotropic displacement parameters of the atoms are given in Table 2. Bond lengths and angles are given in Table 3. The two rings of the $N$-isopropenylbenzimidazolone are nearly planar as found for various benzimidazole derivatives structures [24, 25]. The highest deviation $(-0.017(2) \AA)$ to the mean plane is for N6.

This plane is nearly parallel to the $[1 \overline{10}]$ direction, the angle between the plane and the diagonal is about $8^{\circ}$. The projection of the crystal structure along the $a-c$ plane is shown in Fig. 2. The benzene ring presents standard $\mathrm{C}-\mathrm{C}$ bond lengths. These parameters are in agreement with previous theoretical studies of some heterocyclic derivatives [26] and experimental studies on benzodiazepine derivatives [27, 28]. The short $\mathrm{N}(3)-\mathrm{C}(2)$ distance $(1.359 \AA)$ indicates a slight resonance with the $\mathrm{O}(1)$ and the long $\mathrm{N}(6)-\mathrm{C}(2)$ $(1.385 \AA$ ) distance shows an increase of this resonance due essentially to the isopropenyl group effect. Furthermore, the molecules are stacked with some hydrogen bonds. The most important is $\mathrm{N}(3)-\mathrm{H}(3) \cdots \mathrm{O}(1)$ hydrogen bond with $\mathrm{N}(3) \cdots \mathrm{O}(1)$ distance of $2.827 \AA$ and angle of $171.7^{\circ}$. Other intramolecular hydrogen 
Table 2. Atomic coordinates ( $\AA$ ) and equivalent isotropic displacement parameters $\left(\AA^{2}\right)$ for the non-hydrogen atoms ( $U_{\mathrm{eq}}$ is defined as one third of the trace of the orthogonalized $U_{i j}$ tensor) and isotropic displacement parameters $\left(\AA^{2}\right)$ for hydrogen atoms

\begin{tabular}{l|c|l|l|l}
\hline Atom & $x$ & $y$ & $z$ & $U_{\text {eq }}$ or $U_{\text {iso }}$ \\
\hline O1 & $0.08611(7)$ & $0.08697(18)$ & $0.43663(6)$ & $0.0549(4)$ \\
N3 & $-0.04621(8)$ & $0.2330(2)$ & $0.45683(7)$ & $0.0480(4)$ \\
N6 & $0.03799(7)$ & $0.4075(2)$ & $0.38140(7)$ & $0.0437(4)$ \\
C2 & $0.03140(9)$ & $0.2259(2)$ & $0.42661(8)$ & $0.0436(5)$ \\
C4 & $-0.08974(9)$ & $0.4157(3)$ & $0.43241(8)$ & $0.0427(5)$ \\
C5 & $-0.03668(8)$ & $0.5288(3)$ & $0.38502(7)$ & $0.0410(4)$ \\
C7 & $-0.16984(10)$ & $0.4890(3)$ & $0.44630(9)$ & $0.0534(6)$ \\
C8 & $-0.19541(11)$ & $0.6806(3)$ & $0.41192(10)$ & $0.0577(6)$ \\
C9 & $-0.14237(11)$ & $0.7930(3)$ & $0.36544(10)$ & $0.0574(6)$ \\
C10 & $-0.06161(11)$ & $0.7205(3)$ & $0.35138(9)$ & $0.0505(5)$ \\
C11 & $0.10821(9)$ & $0.4524(3)$ & $0.33499(8)$ & $0.0466(5)$ \\
C12 & $0.12855(14)$ & $0.2777(4)$ & $0.28090(11)$ & $0.0645(7)$ \\
C13 & $0.14668(12)$ & $0.6423(3)$ & $0.34043(12)$ & $0.0643(7)$ \\
H3 & $-0.0643(11)$ & $0.138(3)$ & $0.4902(10)$ & $0.056(5)$ \\
H7 & $-0.2070(11)$ & $0.404(3)$ & $0.4801(11)$ & $0.068(5)$ \\
H8 & $-0.2504(13)$ & $0.734(3)$ & $0.4223(10)$ & $0.067(5)$ \\
H9 & $-0.1617(12)$ & $0.926(3)$ & $0.3425(10)$ & $0.069(5)$ \\
H10 & $-0.0236(10)$ & $0.798(3)$ & $0.3186(9)$ & $0.056(5)$ \\
H12A & $0.0813(17)$ & $0.234(4)$ & $0.2476(13)$ & $0.111(9)$ \\
H12B & $0.1464(15)$ & $0.142(4)$ & $0.3058(13)$ & $0.102(8)$ \\
H12C & $0.1752(15)$ & $0.329(4)$ & $0.2483(13)$ & $0.099(7)$ \\
H13A & $0.1943(13)$ & $0.678(4)$ & $0.3055(11)$ & $0.081(6)$ \\
\hline & $0.1308(13)$ & $0.758(4)$ & $0.3794(12)$ & $0.086(7)$ \\
\hline
\end{tabular}

Table 3. Bond lengths $[\AA ̊]$ and angles [deg]

\begin{tabular}{l|l|l|l|l|l}
\hline \multicolumn{5}{c}{ Bond lengths } \\
\hline N3 & C2 & $1.359(5)$ & C9 & C10 & $1.389(3)$ \\
O1 & C2 & $1.231(2)$ & C11 & C12 & $1.488(3)$ \\
N3 & C4 & $1.386(2)$ & C11 & C13 & $1.315(3)$ \\
N6 & C2 & $1.385(2)$ & C7 & H7 & $1.001(19)$ \\
N6 & C5 & $1.406(2)$ & C8 & H8 & $0.96(2)$ \\
N6 & C11 & $1.433(2)$ & C9 & H9 & $0.963(18)$ \\
N3 & H3 & $0.889(18)$ & C10 & H10 & $0.975(17)$ \\
C4 & C5 & $1.394(2)$ & C12 & H12A & $1.00(3)$ \\
C4 & C7 & $1.380(5)$ & C12 & H12B & $0.99(2)$ \\
C5 & C10 & $1.379(2)$ & C12 & H12C & $1.00(2)$ \\
C7 & C8 & $1.387(2)$ & C13 & H13A & $1.02(2)$ \\
C8 & C9 & $1.382(2)$ & C13 & H13B & $1.03(2)$ \\
\hline
\end{tabular}

Bond angles

\begin{tabular}{|c|c|c|c|c|c|c|c|}
\hline $\mathrm{C} 2$ & N3 & $\mathrm{C} 4$ & $110.68(12)$ & $\mathrm{C} 12$ & C11 & $\mathrm{C} 13$ & $125.30(16)$ \\
\hline $\mathrm{C} 2$ & N6 & $\mathrm{C} 5$ & $109.10(12)$ & N6 & C11 & $\mathrm{C} 13$ & $119.37(16)$ \\
\hline $\mathrm{C} 2$ & N6 & C11 & $124.39(12)$ & $\mathrm{C} 4$ & $\mathrm{C7}$ & H7 & $119.8(10)$ \\
\hline $\mathrm{C} 5$ & N6 & C11 & $126.37(13)$ & $\mathrm{C} 8$ & $\mathrm{C} 7$ & $\mathrm{H} 7$ & $122.7(10)$ \\
\hline $\mathrm{C} 2$ & N3 & H3 & $123.7(12)$ & $\mathrm{C} 7$ & $\mathrm{C} 8$ & $\mathrm{H} 8$ & $117.9(11)$ \\
\hline $\mathrm{C} 4$ & N3 & $\mathrm{H} 3$ & $125.4(12)$ & C9 & $\mathrm{C} 8$ & H8 & 121.2(11) \\
\hline $\mathrm{O} 1$ & $\mathrm{C} 2$ & N3 & $127.62(13)$ & $\mathrm{C} 8$ & C9 & H9 & $119.2(11)$ \\
\hline N3 & $\mathrm{C} 2$ & N6 & $106.65(11)$ & $\mathrm{C} 10$ & C9 & H9 & $119.0(11)$ \\
\hline $\mathrm{O} 1$ & $\mathrm{C} 2$ & N6 & $125.73(13)$ & $\mathrm{C} 5$ & $\mathrm{C} 10$ & H10 & $120.3(10)$ \\
\hline N3 & $\mathrm{C} 4$ & $\mathrm{C} 7$ & $131.79(15)$ & C9 & C10 & H10 & $122.6(10)$ \\
\hline C5 & $\mathrm{C} 4$ & $\mathrm{C} 7$ & $121.27(16)$ & C11 & $\mathrm{C} 12$ & H12A & $115.2(15)$ \\
\hline N3 & $\mathrm{C} 4$ & C5 & $106.92(13)$ & C11 & C12 & H12B & 111.1(14) \\
\hline $\mathrm{C} 4$ & $\mathrm{C} 5$ & $\mathrm{C} 10$ & $121.30(14)$ & C11 & $\mathrm{C} 12$ & $\mathrm{H} 12 \mathrm{C}$ & $109.4(14)$ \\
\hline N6 & C5 & $\mathrm{C} 4$ & $106.63(14)$ & $\mathrm{H} 12 \mathrm{~A}$ & C12 & H12B & $106(2)$ \\
\hline N6 & C5 & $\mathrm{C} 10$ & $132.06(14)$ & H12A & $\mathrm{C} 12$ & $\mathrm{H} 12 \mathrm{C}$ & $106(2)$ \\
\hline $\mathrm{C} 4$ & C7 & $\mathrm{C} 8$ & $117.54(16)$ & H12B & $\mathrm{C} 12$ & $\mathrm{H} 12 \mathrm{C}$ & $109(2)$ \\
\hline $\mathrm{C} 7$ & C8 & C9 & $120.96(16)$ & C11 & $\mathrm{C} 13$ & H13A & $119.5(13)$ \\
\hline $\mathrm{C} 8$ & C9 & $\mathrm{C} 10$ & $121.79(17)$ & C11 & $\mathrm{C} 13$ & H13B & $122.5(13)$ \\
\hline $\mathrm{C} 5$ & $\mathrm{C} 10$ & C9 & $117.11(15)$ & $\mathrm{H} 13 \mathrm{~A}$ & $\mathrm{C} 13$ & H13B & $118.0(18)$ \\
\hline
\end{tabular}

Table 4. Hydrogen bonding geometry $(\AA)$

\begin{tabular}{l|l|l|l|l|l}
\hline \multicolumn{1}{c|}{$\mathrm{D}-\mathrm{H} \Lambda \mathrm{A}$} & $\mathrm{D}-\mathrm{H}(\AA)$ & $\mathrm{H} \Lambda \mathrm{A}(\AA)$ & $\mathrm{D} \Lambda \mathrm{A}(\AA)$ & $\mathrm{D}-\mathrm{H} \Lambda \mathrm{A}(\mathrm{deg})$ & Symmetry code \\
\hline $\mathrm{N}(3)-\mathrm{H}(3) \mathrm{LO}(1)^{\mathrm{S} 1}$ & $0.889(18)$ & $1.946(19)$ & $2.827(2)$ & $171.1(17)$ & $-x,-y,-z+1$ \\
$\mathrm{C}(12)-\mathrm{H}(12 \mathrm{~B}) \mathrm{LO}(1)^{\mathrm{S} 2}$ & $0.99(2)$ & $2.60(3)$ & $3.142(3)$ & $115.1(17)$ & $x, y, z$ \\
$\mathrm{C}(13)-\mathrm{H}(12 \mathrm{C}) \mathrm{LO}(1)^{\mathrm{S} 3}$ & $1.03(2)$ & $2.37(2)$ & $3.373(2)$ & $162.7(18)$ & $x, y+1, z$ \\
\hline
\end{tabular}




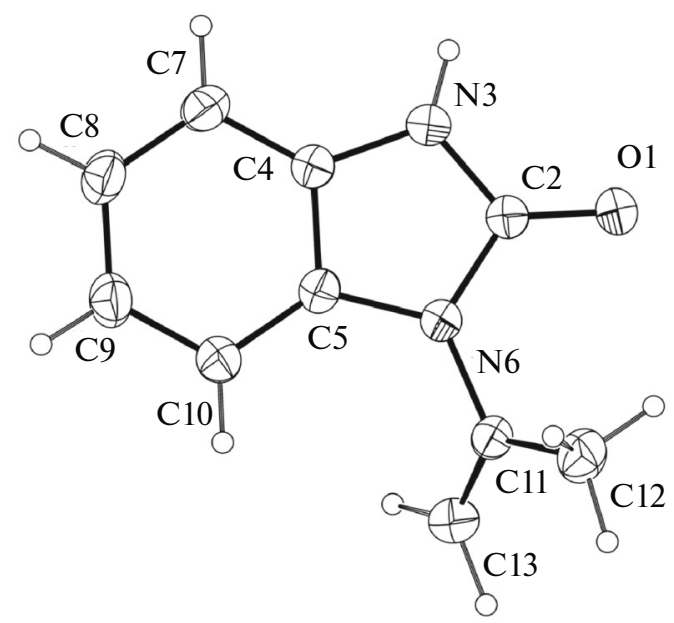

Fig. 1. ORTEP plot of $N$-isopropenylbenzimidazolone with the ellipsoids drawn at the $50 \%$ probability level.

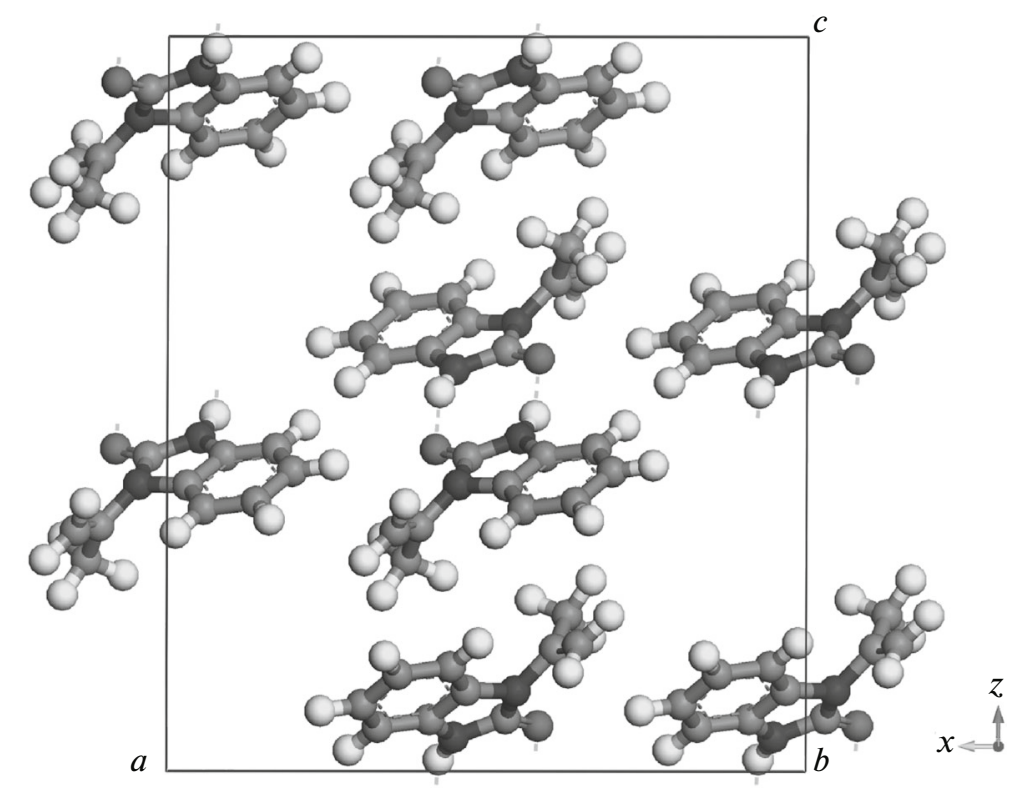

Fig. 2. Projection of the $N$-isopropenylbenzimidazolone crystal structure along the $a, c$-plane. The dashed lines indicate the hydrogen bonds.

bonding chelate withdrawals appear involving $\mathrm{C}(12 \mathrm{~B})-\mathrm{H}(12 \mathrm{~B}) \cdots \mathrm{O}(1)$ and $\mathrm{C}(13)-\mathrm{H}(13 \mathrm{C}) \cdots \mathrm{O}(1)$. The shortest bond lengths are given in Table 4 along with the angles. In Fig. 2, the hydrogen bonds are marked with dashed lines.

\section{CONCLUSIONS}

The synthesis and the single-crystal stucture of the $N$-isopropenylbenzimidazolone molecule is presented. The compound was prepared according to Meth-Cohen method by the reaction of $o$-phenylenediamine with ethyl acetoacetate in refluxing xylene. It crystallizes in a monoclinic system with $C 2 / c$ symme- try. Intra- and intermolecular hydrogen bonds are participating in crystal cohesion. The strongest hydrogen bonds are $\mathrm{N}-\mathrm{H} \cdots \mathrm{O}$ bonds.

\section{ACKNOWLEDGMENTS}

This work has been supported in part by the Morocco-French (CNRST-CNRS) Convention and by the Hassan II Academy of Science and Technology.

\section{REFERENCES}

1. T. Sakar, T. Hamada, N. Awata, and J. Watanabe, J. Pharmacobio-Dyn. 12, 530 (1989). 
2. R. Palin, A. Bom, J. K. Clark, L. Evans, H. Feilden, K. Andrea, Ph. Houghton, S. Jones, B. Montgomery, M. A. Weston, and G. Wishart, Bioorg. Med. Chem. Lett. 15, 1828 (2007).

3. A. Eugene, A. J. Kern, A, Fensome, J. Wrobel, Y. Zhu, J. Cohen, R. Winneker, Z. Zhang, and P. Zhang, Bioorg. Med. Chem. Lett. 15, 3600 (2005).

4. K. L. Yu, Y. Zhang, R. L. Civiello, A. K. Trehan, B. C. Pearce, Z. Yin, K. D. Combrink, B. Gulgeze, X. A. Wang, K. F. Kadow, C. Cianci, M. Krystal, and N. A. Meanwell, Bioorg. Med. Chem. Lett. 14, 1133 (2004).

5. Z. Boruszczak and J. Kraska, Dyes Pigments 25, 59 (1994).

6. S. A. Sokolova and G. L. Mednik, Farmakol. Toksikol. 26, 468 (1973).

7. M. Inoue, J. Saito, K. Arai, S. Kidokoro, and H. Okuzawa, Jpn. Kokai 476, 870 (1974).

8. S. M. Deshpande and K. Naîm, Bull. Chem. Soc. Jpn. 40, 998 (1967).

9. O. Meth-Cohen and D. I. Smith, J. Chem. Soc. Perkin Trans. I, 261 (1982).

10. D. C. Devor, A. K. Singh, R. A. Frizzell, and R. J. Bridges, Am. J. Physiol. 271, 775 (1996).

11. M. M. Htay and O. Meth-Cohen, Tetrahedron Lett. 1, 79 (1976).

12. M. M. Htay and O. Meth-Cohen, Tetrahedron Lett. 6, 469 (1976).

13. B. Lakhrissi, B. El Azzaoui, A. Nabil, E. M. Essassi, M. Massoui, G. Goethals, P. Villa, C. Solans, N. Azemar, F. Comelles, M. J. Garcia-celma, N. Sadurni, and P. Godee, J. Com. Esp. Deterg. 30, 233 (2000).

14. B. Lakhrissi, S. Ejjiyar, M. Massoui, F. Comelles, M. T. Garcia, I. Ribosa, N. Azemar, and C. Solans, J. Com. Esp. Deterg. 32, 365 (2002).
15. B. Lakhrissi, E. Essassi, M. Massoui, G. Goethals, V. Lequart, E. Monflier, R. Cecchelli, and P. Martin, ChemInform. 36 (21) (2005).

16. L. Lakhrissi, N. Hassan, B. Lakhrissi, M. Massoui, E. M. Essassi, J. M. Ruso, C. Solans, and C. Rodriguez-Abreu, J. Surfactants Deterg. 14, 487 (2011).

17. A. Rossi, A. Hunger, J. Kebrle, and K. Hoffman, Helv. Chem. Acta 63, 1298 (1960).

18. Z. Lazar, B. Benali, K. Elblidi, M. Zenkouar, B. Lakhrissi, M. Massoui, B. Kabouchi, and C. Cazeau-Dubroca, J. Mol. Liq. 106, 89 (2003)

19. B. Benali, Z. Lazar, K. Elblidi, B. Lakhrissi, M. Massoui, A. Elassyry, and C. Cazeau-Dubroca, J. Mol. Liq. 128, 42 (2006)

20. L. F. Pacios, Z. Lazar, and B. Benali, J. Mol. Struct. (THEOCHEM) 594, 89 (2002)

21. B. Benali, A. El Assyry, A. Boucetta, Z. Lazar, and B. Lakhrissi, Res. Chem. Intermediat. 41, 821 (2015).

22. G. M. Sheldrick, Acta Crystallogr. A 64, 112 (2008).

23. Materials Science Modeling and Simulation (Materials Studio Product Descriptions). http://www.accelrys.com/products/mstudio/

24. S. D. Quin, S. S. Feng, H. M. Zang, P. Yang, and M. L. Zhu, Acta Crystallogr. E 61, 1574 (2005).

25. S. G. Liu, J. L. Zuo, Y. Z. Li, and X. Z. You, J. Mol. Struct. (THEOCHEM) 705, 153 (2004).

26. L. F. Pacios, Z. Lazar, and B. Benali, J. Mol. Struct. (THEOCHEM) 594, 89 (2002).

27. D. Mondieig, Ph. Négrier, J. M. Léger, B. Benali, Z. Lazar, A. El Assyry, B. Lakhrissi, and M. Massoui, Anal. Sci. 21, 145 (2005).

28. Ph. Négrier, D. Mondieig, J. M. Léger, B. Benali, Z. Lazar, A. Boucetta, A. Elassyry, B. Lakhrissi, C. Jermoumi, and M. Massoui, Anal. Sci. 22, 175 (2006). 